УДК 340.1

Д. В. Рыбин

Санкт-Петербургский институт (филиал) Всероссийского государственного университета юстииии (РПА Минюста России),

г. Санкт-Петербург, Российская Федерации

\title{
ДОРЕВОЛЮЦИОННЫЙ СУДЕБНЫЙ ДЕЯТЕЛЬ, ЮРИСТ-УЧЕНЫЙ И ПЕДАГОГ И. В. МИХАЙЛОВСКИЙ: СОВРЕМЕННИК ИЗ ПРОШЛОГО
}

\begin{abstract}
АннотАция. В статье анализируются жизненный путь, основные труды и публично высказанные позиции по вопросам организации правосудия и статуса судейского корпуса дореволюционного судебного деятеля и юриста-ученого Иосифа-Стефана Викентьевича Михайловского. Автором отмечается особенность статуса Михайловского в момент написания своих главных работ - одновременно он являлся судебным деятелем, а, следовательно, сотрудником Министерства юстиции, а с другой он решительно и последовательно критиковал судоустройство и кадровую политику Министерства юстиции. В статье особое внимание уделяется последовательному отстаиванию либеральных ценностных установок в работах И. В. Михайловского, его приверженности демократических принципов организации правосудия. Показаны ярко выраженное в трудах И. В. Михайловского сравнение организации отечественных судебных установлений с их западноевропейскими аналогами и выработанные на основе такого сравнения меры совершенствования отечественного законодательства, которые способствовали бы правильной и эффективной работе суда.

кЛючЕВЫЕ СлОВА. Дореволюционное судоустройство; Судебная реформа 1864 г.; кадровая политика судов; несменяемость судей; материальное обеспечение судейского корпуса.

ИНФОРМАЦИЯ О СТАТЬЕ. Дата поступления 19 декабря 2016 г.; дата принятия к печати 11 января 2017 г.; дата онлайн-размещения 31 марта 2017 г.
\end{abstract}

D. V. Rybin

Saint-Petersburg Branch of All-Russian State University of Justice

(Russian Law Academy),

Saint-Petersburg, Russian Federation

\section{PRE-REVOLUTIONARY JUDICIAL ACTIVIST, LAWYER, SCIENTIST AND EDUCATOR I.V. MIKHAILOVSKY: A COEVAL FROM THE PAST}

\begin{abstract}
The article analyzes the life path, main works and publicly expressed positions on issues of organization of justice and the status of judiciary of pre-revolutionary judicial activist, lawyer, scientist and educator Joseph- Stephen Vikentievich Mikhailovsky. The author notes the features of Mikhailovsky's status at the moment of writing of his major works - at the same time, he was a judicial figure and, consequently, an employee of the Ministry of Justice, on the other hand, he strongly and consistently criticized the judicial system and the personnel policy of the Ministry of Justice. The article focuses on the consistent upholding of liberal set of values in the works of I. V. Mikhailovsky, his commitment to democratic principles of justice organization. The article shows clearly expressed in the I. V. Mikhailovsky's writings the comparison of organization of the domestic judicial system between its West European analogues and the measures of improving the national legislation developed on the basis of this comparison, which would contribute to the proper and efficient operation of the court.

KEYWORDS. Pre-revolutionary judicial system; judicial reform of 1864; personnel policy of courts; irremovability of judges; material support of judges.

ARTICLE INFO. Received December 19, 2016; accepted January 11, 2017; available online March 31, 2017.
\end{abstract}

\section{Baikal Research Journal}


Иосиф-Стефан Викентьевич Михайловский принадлежит к числу наиболее заметных дореволюционных судебных деятелей и юристов-ученых, однако, его имя, на наш взгляд, незаслуженно забыто в современной юридической России. Он оставил после себя значимое творческое наследие, включающее в себя научно-исследовательские и публицистические работы по философии права, уголовному праву, судоустройству ${ }^{1}$, а также по истории и общим вопросам музыки. Видный государственный деятель той эпохи С. Ю. Витте характеризовал И. В. Михайловского как одного из наиболее даровитых, просвещенных и полезных представителей мирового института Томской губернии ${ }^{2}$.

Для современного российского общества особое значение и актуальность, на наш взгляд, имеют труды И. В. Михайловского, посвященные осмыслению положению суда и судебных деятелей после судебной реформы 1864 года. Здесь необходимо обратить внимание, что в XIX столетии Министерство юстиции занималось управлением системой суда и прокуратуры (заведованием личным составом, учреждением и упразднением судов, надзором за их деятельностью и т. д.) [1, с. 180], сфера компетенции Министерства юстиции значительно расширилась после судебной реформы 1864 г., [2, с. 138] в 1870 г. в структуре министерства создается Межевое управление, а с 1895 г. в состав Министерства юстиции входит переведенное из Министерства внутренних дел Главное тюремное управление. В этой связи И. В. Михайловский был в весьма своеобразной ситуации, так как с одной стороны, он был судебным деятелем (то есть состоял в трудовых правоотношениях с Министерством юстиции), а с другой стороны, как ученый-юрист критически анализировал российское судоустройство и кадровую политику министерства, в котором трудился. Вместе с тем, воззрения И. В. Михайловского на кадровую политику Министерства юстиции Российской империи тем и интересны, что это как бы "взгляд изнутри», т. е. умозаключения не только ученого-теоретика по конкретному вопросу, а еще и судебного деятеля, который на практической работе сталкивался со многими проблемами, о которых позже писал.

Свои взгляды на проблемы пореформенной кадровой политики Министерства юстиции И. В. Михайловский изложил главным образом в двух работах — «К вопросу об уголовном судье. По поводу предстоящей судебной реформы» и «Общий обзор проекта нового судоустройства» ${ }^{3}$. Если первая работа была опубликована для широкой аудитории [3], то вторая была представлена в качестве доклада, с которым И.В. Михайловский выступил 4 ноября 1900 г. в Киевском юридическом обществе при Киевском университете им. Святого Владимира ${ }^{4}$.

И. В. Михайловский (1867-1920) родился в Могилеве Черниговской губернии, происходил из мещан, по вероисповеданию был католиком, образование получил в Киевском университете им. Святого Владимира (учился на истори-

\footnotetext{
${ }^{1}$ К важнейшим трудам И. В. Михайловского следует отнести следующие: $К$ вопросу об уголовном судье. По поводу предстоящей судебной реформы. Нежин, 1898; Основные принципы организации уголовного суда. Томск, 1905; Очерки философии права. Томск, 1914 и др.

${ }^{2}$ Российский государственный исторический архив (РГИА). Ф. 1405. Оп. 538. Д. 74. Л. 155.

${ }^{3}$ В этом докладе И. В. Михайловский критически проанализировал проект судоустройства, предложенный «Комиссией для пересмотра законоположений по судебной части», которая работала под руководством министра юстиции Н. В. Муравьева, отсюда еще одно название этой комиссии - «Муравьевская комиссия».

${ }^{4}$ Данный доклад автор настоящей статьи обнаружил в фондах РГИА.
}

\section{Baikal Research Journal}


ко-филологическом и юридическом факультетах) ${ }^{5}$. Публиковал свои научные работы в «Вестнике Славянства», «Праве», «Вестнике Права», «Журнале Министерства юстиции», «Судебной газете», «Юридической газете», «Образовании», «Вопросах философии и психологии» и других изданиях.

Профессиональный рост И. В. Михайловского как судебного деятеля поначалу складывался довольно успешно: в 1890 г. он поступил на службу по Министерству юстиции кандидатом на судебные должности ${ }^{6}$ при Нежинском окружном суде (Черниговская губерния), в 1893 г. он уже был назначен городским судьей г. Екатеринбурга (Пермская губерния), а с 1896 г. состоял городским судьей г. Козельца (Черниговская губерния).

И. В. Михайловский отличался незаурядными профессиональными качествами, его судебная деятельность характеризовалась как в высшей степени образцовая, работал он много и быстро, обладал глубокими познаниями, среди коллег пользовался авторитетом ${ }^{7}$. Его решения и приговоры редко отклонялись, однако размер наказаний налагаемых им, часто уменьшались уездным съездом, так как он имел склонность назначать наказания в высшем размере. Последнее и стало причиной нелюбви к нему населения г. Козельца ${ }^{8}$.

И. В. Михайловский как личность, отличался сложным, противоречивым и неуживчивым характером, причем это отмечали люди, которые с ним работали в разные периоды его жизни. В частности, И. В. Михайловскому было свойственно чрезмерное самолюбие, нетерпимость $\kappa$ мнению других, не проявлял он сдержанности и чувства меры в общении с сослуживцами и чиновниками Министерства юстиции ${ }^{9}$. В «томский период» его жизни И. В. Михайловского за строгость к студентам характеризовали как «одиозный профессор" [4, с. 19-20]. Такие черты характера И. В. Михайловского, а также его активная общественно-политическая позиция, по-видимому, способствовали тому, что его часто переводили в разные губернии империи. В начале 90-х гг. XIX столетия И. В. Михайловский получил назначение в Лифляндскую губернию, где работал мировым судьей 3-го участка в г. Юрьев, однако в 1903 г. он был переведен в Томск мировым судьей первого участка. В 1906 г. И. В. Михайловский был уволен из Министерства юстиции, это, по-видимому, стало следствием того, что в разгар революции 1905 г. он вместе со своими коллегами из Томского технологического института подписал два постановления с политическими воззваниями, в частности, в одном из них было требование «участия свободно избранного народного представительства в осуществлении законодательной власти и в контроле над администрацией и бюджетом» ${ }^{10}$. Кроме того, есть данные, что И. В. Михайловский в указанный период был членом Томской организации партии народной свободы [4, с. 19]. Общественно-политическая деятельность И. В. Михайловского вызвала такой резонанс, что он был вынужден письменно объясняться перед министром юстиции Российской империи, а действительный тайный советник С. Ю. Вит-

${ }^{5}$ РГИА. Ф. 1405. Оп. 538. Д. 74. Л. 4.

${ }^{6}$ Кандидат на судебные должности - в дореволюционной России начальная ступень служебной лестницы в Министерстве юстиции; кандидатами на должность по судебному ведомству могли быть лица, получившие высшее образование. Кандидаты на судебные должности назначались министром юстиции, председателями общих судебных мест или обер-прокурорами кассационных департаментов Правительствующего Сената, они состояли при судебных местах и при прокурорском надзоре. Кандидаты на судебные должности считались состоящими на государственной службе, но жалованья не получали.

${ }^{7}$ РГИА. Ф. 1405. Оп. 538. Д. 74. Л. 5.

${ }^{8}$ Там же.

${ }^{9}$ Там же. Л. 5-6.

10 Там же.

\section{Baikal Research Journal}

электронный научный журнал Байкальского государственного университета 
те даже ходатайствовал за И. В. Михайловского, отмечая его даровитость и полезность для мировой юстиции Томской губернии ${ }^{11}$.

Отличительная черта личности И. В. Михайловского - его склонность к научно-педагогической деятельности. Еще в начале своей карьеры судебного деятеля, в 1900 г. он выдержал магистерский экзамен и прочитал в Киевском университете две публичные лекции. И на экзаменах, и на лекциях И. В. Михайловский произвел отличное впечатление на членов юридического факультета. По итогам этих испытаний он получил от университета свидетельство на право приват-доцентуры и тогда же был избран в члены Киевского юридического общества.

В 1903 г. И. В. Михайловский получил назначение в Сибирь и продолжи совмещать работу судьи и научно-педагогическую деятельность. Он устроился приват-доцентом в Томский технологический институт на кафедру законодательства общего и промышленного, где читал лекции по законоведению и занимался научной работой. В 1906 г. на первом юридическом диспуте в Томском университете И. В. Михайловский защитил диссертацию на степень магистра уголовного права.

В период с 1912 по 1913 гг. И. В. Михайловский работал секретарем юридического факультета, а с 17 мая по 4 сентября 1913 г. - деканом этого факультета [4, с. 19].

В годы революции и Гражданской войны И. В. Михайловский определил свою политическую позицию, как у большинства вузовской интеллигенции Томска, его отношение к октябрьским событиям 1917 г. и установлению Советской власти было негативным [5]. В период 1918-1919 гг., когда Сибирь находилась вне Советского государства, являясь одним из центров антибольшевистского движения, И. В. Михайловский получил несколько важных назначений. Так, например, в сентябре 1918 г. И. В. Михайловский был назначен членом Высшего сибирского суда по Уголовному департаменту с правом чтения лекций, в июле 1919 г. он был назначен почетным мировым судьей [4, с. 20]. После установления в конце 1919 г. Советской власти в Томской губернии последовала быстрая реакция на общественно-политическую позицию И. В. Михайловского и его сотрудничество с предыдущим режимом. В декабре 1919 г. И. В. Михайловский был уволен с должности профессора, в 1920 г. осужден на пять лет лишения свободы. В мае 1920 г. И. В. Михайловского освободили из заключения в связи с просьбой ректора Томского университета А. П. Поспелова, а также по состоянию здоровья. Умер И. В. Михайловский в том же 1920 г. в больнице от кардиосклероза [4, с. 20].

Центральной идеей в работах И. В. Михайловского была независимость судейского корпуса. В период подготовки и после проведения судебной реформы 1864 г. демократические принципы судопроизводства, «посеянные на российской почве», не успев толком прижиться, подверглись резкой критике со стороны консервативных авторов [6;7]. В период правления императора Александра III эти голоса стали крепче и громче, а самое главное - соответствовали взглядам самого самодержца. В немалой степени этому способствовал оправдательный приговор террористке В. И. Засулич, который был вынесен в 1878 г. Петербургским окружным судом под председательством А. Ф. Кони с участием присяжных заседателей. В этой связи власть взяла курс на ограничение независимости судей. Так, в 1885 г. был нанесен серьезный удар по принципу несменяемости судей, а именно: установлен особый

${ }^{11}$ РГИА. Ф. 1405. Оп. 538. Д. 74. Л. 155.

\section{Baikal Research Journal}

электронный научный журнал Байкальского государственного университета 
порядок удаления судей от должности. Соответствующие полномочия были вверены образованному в составе Правительствующего Сената особому Высшему дисциплинарному присутствию. Этим же законом усилена и расширена власть министра юстиции по надзору за судебными установлениями. В 1889 г. была ликвидирована мировая юстиция, за исключением столиц и Одессы, и передано ведение ранее подсудных ей дел в руки местных административных органов - земским начальникам, а в городах - назначаемым городским судьям.

В период 1894-1899 гг. при Министерстве юстиции работала комиссия для пересмотра законоположений по судебной части, получившая свое название по фамилии тогдашнего министра юстиции - «Муравьевская комиссия». Несмотря на то, что в начале работы комиссии было заявлено, что основные начала Судебных уставов 1864 г. должны остаться непоколебимы, в проекте нового изложения уставов было вообще исключено положение о судейской несменяемости, значительно расширена власть министра юстиции, резко расширен круг лиц, которым может быть представлено право ревизии судов и многое другое.

$\mathrm{C}$ точки зрения консервативной идеологии того периода, в результате судебной реформы 1864 г. произошло выделение судебной власти из общей компетенции верховной власти монарха, а некоторые авторы и вовсе усматривали в судебных уставах своего рода политический habeas corpus -отправную точку конституционных порядков [7, с. 2]. Лидер консерваторов К. П. Победоносцев в 1881 г. в письме к императору Александру III писал, что «бесконтрольная, обособленная юстиция не совместима с самодержавием» как типом верховной власти [8, с. 160].

Наконец, для того чтобы осознать всю сложность положения И. В. Михайловского, обратимся к документу, который хранится в фондах РГИА и позволяет нам «из первых уст» услышать позицию императора Александра III в отношении сотрудников Министерства юстиции, которые относились критически к пересмотру Судебных уставов 1864 г. Самодержец работая с отчетами губернаторов Бессарабской и Эриванской губерний за 1892 г. прочитав, что некоторые чины Министерства юстиции относятся равнодушно к реформе 12 июля 1889 г. исходя из того, что теория права не допускает соединения административной и судебной власти отреагировал следующим образом: «Это, к сожалению, я слышу не в первый раз и обращаю самое серьезное внимание министра юстиции на эти непростительные факты требуя от него самых энергичных мер к прекращению их" ${ }^{12}$. А на полях отчета Бессарабского губернатора, где последний выразил опасение, что такие воззрения, особенно лиц, юридически образованных, могут дать повод разным темным личностям надеяться на проведение своих злорадных дел, император написал: «Это не должно допустить», при этом поставил три восклицательных знака и слова «юридически образованных» подчеркнул ${ }^{13}$.

И. В. Михайловский не был согласен с пересмотром основополагающих принципов Судебной реформы 1864 г. В своих работах он последовательно отстаивал идею судейской несменяемости. В частности, на критику консерваторов принципа несменяемости судей, он остроумно и точно отвечал, что начало несменяемости противоречит не самодержавию монарха, а самодержавию министра юстиции, так как только по докладу министра монарх смещает судью [3, с. 33].

\footnotetext{
${ }^{12}$ РГИА. Ф. 1405. Оп. 539. Д. 14. Л. 1.

${ }^{13}$ Там же. Л. 1-2.
}

\section{Baikal Research Journal}

электронный научный журнал Байкальского государственного университета 
И действительно, судебные деятели той эпохи с тяжелыми чувствами вспоминали поездки в Санкт-Петербург в Министерство юстиции империи (ул. Малая Садовая д. 1), осознавая, что их профессиональная судьба во многом зависит от чиновников министерства. Один из судебных деятелей так описывал свое состояние и атмосферу при посещении министерства: «Кто не испытывал, проделывая это, тягостное и удручающее чувство какой-то приниженности, беспомощности, чего-то обидного, ходя по отделениям и канцеляриям и ожидая в маленькой приемной министра, когда Его Высокопревосходительство изволит принять Вас в своем кабинете. Везде начальство, даже курьеры и сторожа... и те посматривают с снисходительностью, важностью и небрежностью, чуть-чуть свысока, в особенности стоящие у дверей кабинетов директора 2-го департамента или начальника отделения личного состава. Ведь все эти директора и начальники отделений держат в своих руках хотя бы кусочек Вашей служебной карьеры... Будучи уже старшим Председателем, и тогда даже я испытывал чувство приниженности и беспомощности, сидя в ожидании в приемной министра. Так было не по себе» ${ }^{14}$. Именно об этом писал И. В. Михайловский, что при таком положении дел судьи всецело отдаются в руки министра, и независимость суда перестает существовать. А министерство получает возможность влиять на состав лиц, которым вверяется судебная власть, и направлять их деятельность в нужном ему русле. Таким образом, И. В. Михайловский констатировал, что такая политика министерства ведет к превращению судей в чиновников, которые лишь проводят волю свыше, а отнюдь не осуществляют правосудие. По мысли И. В. Михайловского, никакого начальника над собой, кроме закона, судья иметь не может, в противном случае извратилось бы понятие судьи, который во время священнодействия, которое называется отправление правосудия, олицетворяет собой особу представителя верховной власти ${ }^{15}$.

Таким образом, И. В. Михайловский отрицал в деле правосудия субординацию и чинопочитание, однако, он признавал необходимость контроля над деятельностью судебного корпуса, установления более строгих наказаний для судьи, нарушившего свой долг ${ }^{16}$. Последнее, по его мнению, принесет только пользу судейскому делу, но искажавшим идею суда он считал умозаключение о необходимости превращение судебного ведомства в новую отрасль администрации ${ }^{17}$.

Еще одной острой проблемой кадровой политики Министерства юстиции, которая волновала И. В. Михайловского, был вопрос о материальном достатке судей. Составители судебных уставов хорошо понимали, что своеобразным «ключом» к успеху предстоящей реформы является подбор квалифицированных кадров. Поэтому они предполагали обеспечить службу в судебном ведомстве такими условиями, которые привлекали бы на эту службу и удерживали бы на ней лиц, достойных звания судьи. Одним из наиболее существенных в числе этих условий должно было стать достаточное материальное обеспечение судебных деятелей, как во время службы, так и после их выхода в отставку. Это хорошо понимал министр юстиции Д. Н. Замятнин, который в своей речи в Государственном совете подчеркивал, что если судебное ведомство не будет в состоянии привлечь и удержать способных и честных деятелей, то несменяемость судей принесет больше вреда, чем пользы [9, с. 244]. В этой связи было

\footnotetext{
${ }^{14}$ Записки судьи. СПб., 1912. С. 26.

${ }^{15}$ РГИА. Ф. 1405. Оп. 538. Д. 74. Л. 10.

${ }^{16}$ Там же. Л. 12.

17 Там же.
}

\section{Baikal Research Journal}

электронный научный журнал Байкальского государственного университета 
даже предложение на первые три года лишить судей несменяемости, чтобы так исправить неудачные назначения. Государственный совет решительно отклонил такую идею ${ }^{18}$.

Первые годы после Судебной реформы 1864 г. материальное обеспечение и социальные гарантии сотрудников судебного ведомства были более чем приемлемые, однако с течением времени, главным образом из-за роста цен, они значительно ухудшились. Заработная плата была настолько незначительной, что для некоторых должностей сводилась к отказу в удовлетворении самых насущных потребностей ${ }^{19}$. Из-за сложных бытовых и материальных условий службы из его рядов «вымывались» наиболее достойные и, зачастую, в судебное ведомство попадали люди неспособные, нерадивые, не обладающие надлежащими нравственными качествами. В 1882 г. А. Ф. Кони так охарактеризовал эту ситуацию: «...явились на смену судебным деятелям современные судебные чиновники, со смелостью незнания, без «вчерашнего дня» и с аппетитами исключительно карьеристического свойства» [10, с. 50].

И.В. Михайловский отмечал, что судья, который находится в заботах от удовлетворении насущных потребностей жизни, лишенный обеспеченности, опасающийся за будущее, поставленный не на должную служебную высоту, теряет необходимое спокойствие духа и уверенность в себе, не пользуется надлежащим авторитетом и превращается в заурядного чиновника средней руки, мечтающего о лучшем месте [3, с. 26]. В своих работах ученый сравнивал организацию работы и материальный достаток российских и западноевропейских судей. В частности, И. В. Михайловский обращал внимание на значительно лучшее вознаграждение своих зарубежных коллег. В этой связи он писал: «вестминстерские судьи, составляющие все в совокупности высший суд Англии и разъезжающие по стране для председательствования в судах присяжных, получают на наши деньги по 50 тыс. рублей в год, а каждый из так называемых полицейских судей, разбирающих дела единолично, около 14 тыс. рублей, ...английский судья выйти в отставку с пенсией после 15 лет службы» [3, с. 29]. В это же время заработная плата сотрудников судебного ведомства Российской империи была на порядки ниже и составляла у старшего члена окружного суда -2700 , товарища (заместителя) прокурора окружного суда - 2500, товарища председателя окружного суда и прокурора окружного суда -3500 , члена судебной палаты - 3500, товарища прокурора судебной палаты - 4000 рублей в год [11, с. 142]. Здесь важно обратить внимание, что жалованье, определенное судебным деятелям в период Судебной реформы 1864 г., оставалось неизменным вплоть до 90-х гг. XIX в., несмотря на значительный рост цен и, как следствие, резкое удорожание жизни, особенно в крупных городах.

По мысли И. В. Михайловского, для возведения прочного здания правосудия в России, судья должен быть так обеспечен, чтобы его не тянуло к другой должности, лучше оплачиваемой, чтобы он был заинтересован в сохранении занимаемого места, чтобы лучшие юристы стремились получить должности судей [3, с. 27-28].

Беспокоила И. В. Михайловского и проблема научной подготовки судебных деятелей. Он отмечал, что уровень научных знаний у судебных деятелей понизился, часто судьи имеют очень смутные понятия о науке, относятся к ней даже свысока, а альфу и омегу юридических знаний видят в кассаци-

\footnotetext{
${ }^{18}$ Министерство юстиции (1802-1902) // Журнал Министерства юстиции. 1903. № 2. С. 14.

19 Общий обзор деятельности Министерства юстиции и Правительствующего Сената за царствование императора Александра III. СПб., 1901. С. 70.
}

\section{Baikal Research Journal}


онных решениях и законах с комментариями Таганцева, Щегловитова, Боровиковского $^{20}$. И. В. Михайловский был убежден, что судья должен принадлежать к умственной аристократии страны, [3, с. 35-36] в этой связи он предлагал Министерству юстиции, наряду с увеличением заработной платы судей, ужесточить требования, касающиеся их научной и практической подготовки [Там же, с. 79].

Красной нитью в трудах И. В. Михайловского проходит сравнение организации отечественных судебных установлений с их западноевропейскими аналогами как своего рода эталоном, часто ученый ссылается на «вековой опыт культурных народов» и «культурных государств». С таким подходом можно вполне согласиться, так как в ходе Судебной реформы 1864 г. российский суд заимствовал западноевропейские принципы своей организации. В этой связи объяснимо желание исследователя сравнить адаптацию новых судебных установлений на российской почве с эталонным образцом.

Обращает на себя внимание конструктивный подход И. В. Михайловского по осмыслению положения суда и судебных деятелей в пореформенной Российской империи. Ученый не только критиковал окружающую его действительность, но и формулировал совершенно конкретные предложения по улучшению работы судебных установлений. В частности, он предлагал следующие меры, которые, по его мнению, должны способствовать более правильной и эффективной работе суда. Во-первых, последовательно провести полное обособление суда от администрации. Во-вторых, улучшить материальное обеспечение судейского корпуса (через периодические прибавки к заработной плате, увеличение пенсий, уменьшение срока для выходы судьи на пенсию). В-третьих, поднять общественное положение судей (при существовании одного только типа судьи дать судьям IV класс должности, а председателям - III. B-четвертых, значительно повысить требования к научной и практической подготовке судей.

Таким образом, И. В. Михайловский в своих работах проанализировал пореформенную кадровую политику Министерства юстиции (в том числе проект комиссии Н.В. Муравьева по пересмотру законоположений по судебной части), подверг ее серьезной критике, выявил ее недостатки и сформулировал предложения по ее улучшению. Воззрения И. В. Михайловского отличаются либеральными ценностными установками, он был сторонником демократических принципов организации правосудия, выступал против пересмотра основных начал Судебных уставов 1864 г. И. В. Михайловский предлагал судебному ведомству альтернативную кадровую политику, основанную на идеях независимости суда и несменяемости судей.

Нельзя не отметить, что мысли И. В. Михайловского, которые он смело высказывал и отстаивал больше ста лет назад, сегодня звучат очень по-современному. В настоящее время идеи И. В. Михайловского по организации правосудия и статуса судейского корпуса являются основополагающими для любого цивилизованного общества, ориентирующего на императивы правового государства. В то же время в конце XIX столетия нужно было обладать гражданской смелостью, чтобы вести острую публичную дискуссию с властью, являясь при этом сотрудником Министерства юстиции.

Своими работами и профессиональной деятельностью дореволюционный судебный деятель, ученый и педагог И. В. Михайловский внес свой вклад в формирование на российской почве традиции правового государства.

${ }^{20}$ РГИА. Ф. 1405. Оп. 538. Д. 74. Л. 18.

\section{Baikal Research Journal}

электронный научный журнал Байкальского государственного университета 


\section{Список использованной литературы}

1. Высшие органы государственной власти и управления России. IX-XX вв. : справочник / под ред. А. С. Турагаева. - СПб. : Изд-во Сев.-Зап. акад. гос. службы : Образование - Культура, 2000. - 368 с.

2. Рыбинская Е. Т. Состязательность уголовного процесса - историко-теоретический аспект / Е. Т. Рыбинская // Вестник молодых ученых : юбил. прил. к «Известиям ИГЭА» (к 75-летию БГУЭП) / под науч. ред. В. И. Самарухи. - Иркутск : БГУЭП, 2004. C. $135-140$.

3. Михайловский И. В. К вопросу об уголовном судье. По поводу предстоящей судебной реформы / И. В. Михайловский. - Нежин : Типо-литогр. М. В. Глезера, 1898. - 92 с.

4. Звягин С. П. Научная, учебная и общественная деятельность профессора Томского университета И. В. Михайловского / С. П. Звягин // Интеллектуальный и индустриальный потенциал регионов России : материалы II Всерос. науч. чтений, 21 дек. 2001 г. - Кемерово : Кузбассвузиздат, 2002. - С. 19-20.

5. Михеенков Е. Г. Вузовская интеллингенция города Томска в годы революции и Гражданской войны, февраль 1917 - конец 1919 гг. : автореф. дис...канд. ист. наук : 07.00 .02 / Е. Г. Михеенков. - Томск, 2012. - 26 с.

6. Катков М. Н. О современных вопросах России (1879-1887) / М. Н. Катков. - М. : Унив. тип., 1898. -42 с.

7. Фукс В. Я. Суд и полиция : в 2 ч. / В. Я. Фукс. - М. : Унив. тип., 1889. -232 с.

8. Тимошина Е. В. Политико-правовая идеология русского пореформенного консерватизма: К. П. Победоносцев / Е. В. Тимошина. - СПб. : Изд-во С.-Петерб. гос. ун-та, 2000. $-202 \mathrm{c}$.

9. Кони А. Ф. Собрание сочинений : в 8 т. / А. Ф. Кони ; под общ. ред. В. Г. Базанова, Л. Н. Смирнова, К. И. Чуковского. - М. : Юрид. лит., 1967. - Т. 4. - 544 с.

10. Кони А. Ф. Собрание сочинений : в 8 т. / А. Ф. Кони ; под общ. ред. В. Г. Базанова, Л. Н. Смирнова, К. И. Чуковского. - М. : Юрид. лит., 1969. - Т. 8 : Письма. 1868-1927. - 528 c.

11. Бабушкин С. Д. Предстоящая судебная реформа / С. Д. Бабушкин. - Казань : Тип.-литогр. Имп. ун-та, 1897. - 234 с.

\section{References}

1. Turagayev A. S. (ed.). Vysshie organy gosudarstvennoi vlasti $i$ upravleniya Rossii. $I X-X X v v$. Spravochnik [Supreme bodies of Russia's state authority and administration. IX-XX centuries. Reference book]. Saint Petersburg, North-West Institute of Management of the Russian Federation Presidential Academy of National Economy and Public Administration Publ., Obrazovanie - Kultura Publ., 2000. 368 p.

2. Rybinskaya E. T. Competitiveness of criminal procedure - historical and theoretical aspect. In Samarukha V. I. (ed.). Vestnik molodykh uchenykh [Bulletin of Young Scientists]. Irkutsk, Baikal State University Economics and Law Publ., 2004, pp. 135-140. (In Russian).

3. Mikhailovsky I. V. K voprosu ob ugolovnom sud'e. Po povodu predstoyashchei sudebnoi reformy [On issue of the criminal judge on the occasion of forthcoming judicial reform]. Nezhin, M. V. Glezer Publ., 1898. 92 p.

4. Zvyagin S. P. Scientific, class and public activity of Tomsk University Professor I. V. Michailovsky. Intellektual'nyi $i$ industrial'nyi potentsial regionov Rossii. Materialy II Vserossiiskikh nauchnykh chtenii, 21 dekabrya $2001 \mathrm{~g}$. [Intellectual and industrial potential of Russia's regions. Materials of II All-Russian Scientific Readings, Dec. 21, 2001. Kemerovo, Kuzbassvuzizdat Publ., 2002, pp. 19-20. (In Russian).

5. Mikheyenkov E. G. Vuzovskaya intellingentsiya goroda Tomska $v$ gody revolyutsii $i$ Grazhdanskoi voiny, fevral' 1917 - konets 1919 gg. Avtoref. Kand. Diss. [University intelligentsia of Tomsk City in the days of revolution and Civic War, February 1917-end of 1919. Cand. Diss. Thesis]. Tomsk, 2012. 26 p.

6. Katkov M. N. O sovremennykh voprosakh Rossii (1879-1887) [On modern issues of Russia (1879-1887)]. Moscow, Universitetskaya tipografiya Publ., 1898. 42 p.

7. Fuks V. Ya. Sud i politsiya [Court and police]. Moscow, Universitetskaya tipografiya Publ., 1889. 232 p.

\section{Baikal Research Journal}


8. Timoshina E. V. Politiko-pravovaya ideologiya russkogo poreformennogo konservatizma: K. P. Pobedonostsev [Political and legal ideology of Russian after-reform conservatism: K. P. Pobedonostsev]. Saint Petersburg State University Publ., 2000. 202 p.

9. Koni A. F.; Bazanov V. G., Smirnov L. N., Chukovsky K. I. (eds). Sobranie sochinenii [Collection of Works]. Moscow, Juridical Literature Publ., 1967. Vol. 4. 544 p.

10. Koni A. F.; Bazanov V. G., Smirnov L. N., Chukovsky K. I. (eds). Sobranie sochinenii [Collection of Works]. Moscow, Juridical Literature Publ., 1967. Vol. 8. 528 p.

11. Babushkin S. D. Predstoyashchaya sudebnaya reforma [Forthcoming judicial reform]. Kazan, ImperailUniversity, Publ., 1897. 234 p.

\section{Информация об авторе}

Рыбин Данил Вячеславович - кандидат исторических наук, доцент, директор, Санкт-Петербургский институт (филиал) Всероссийского государственного университета юстиции (РПА Минюста России), 199178, г. Санкт-Петербург, В.О., 10-я линия, 19А, e-mail: danilarybin@rambler.ru.

\section{Author}

Danil V. Rybin - PhD in Law, Associate Professor, Saint-Petersburg Branch of All-Russian State University of Justice (Russian Law Academy), 10-th line 19-A, Vasilyevsky Island, 199178, Saint-Petersburg, Russian Federation; e-mail: danilarybin@rambler.ru.

\section{Библиографическое описание статьи}

Рыбин Д. В. Дореволюционный судебный деятель, юрист-ученый и педагог И. В. Михайловский: современник из прошлого / Д. В. Рыбин // Baikal Research Journal. - 2017. T. 8, № 1. - DOI: 10.17150/2411-6262.2017.8(1).26.

\section{Reference to article}

Rybin D. V. Pre-revolutionary judicial activist, lawyer, scientist and educator I. V. Mikhailovsky: a coeval from the past. Baikal Research Journal, 2017, vol. 8, no. 1. DOI: 10.17150/24116262.2017.8(1).26. (In Russian).

\section{Baikal Research Journal}

